CZASOPISMO INŻYNIERII LA¿DOWEJ, ŚRODOWISKA I ARCHITEKTURY JOURNAL OF CIVIL ENGINEERING, ENVIRONMENT AND ARCHITECTURE

JCEEA, t. XXXIV, z. 64 (4/I/17), październik-grudzień 2017, s. 177-184, DOI:10.7862/rb.2017.204

Mateusz SZUBEL ${ }^{1}$

Magdalena PAPKA ${ }^{2}$

Mariusz FILIPOWICZ ${ }^{3}$

\title{
ZASTOSOWANIE OBLICZENIOWEJ MECHANIKI PLYNÓW W WIELOWARIANTOWEJ ANALIZIE HOMOGENICZNEGO SPALANIA PRODUKTÓW ZGAZOWANIA BIOMASY
}

\begin{abstract}
Z uwagi na konieczność dywersyfikacji źródeł energii, pod koniec ubiegłego stulecia uwaga producentów kotłów zwróciła się ku technologiom opartym na odnawialnych surowcach energetycznych. Dużą popularność zyskała biomasa pochodzenia roślinnego, obecnie coraz częściej stosowana do produkcji ciepła w energetyce rozproszonej. Na terenach wiejskich stosowanie kotłów wsadowych zasilanych słomą niesie za sobą znaczne korzyści ekonomiczne. Jednostki te są także przyjazne środowisku, przy czym z uwagi na dużą zawartość części lotnych w paliwie i intensywność jego zgazowania w komorze spalania, proces musi być prowadzony przy zapewnieniu odpowiedniej konstrukcji systemu podawania powietrza, a także przy zastosowaniu dedykowanego algorytmu sterującego w/w systemem. Niniejszy artykuł opisuje analizę CFD kotła wsadowego o mocy $100 \mathrm{~kW}$, zasilanego słomą w postaci prostopadłościennych balotów. Konstrukcja analizowanej jednostki grzewczej została opracowana na podstawie wyników prac eksperymentalnych i numerycznych przeprowadzonych na kotle wsadowym o standardowej konstrukcji. Do budowy modelu numerycznego i przeprowadzenia obliczeń wykorzystano moduły pakietu ANSYS Workbench 15. Dyskretyzację domeny ciągłej przeprowadzono narzędziem ANSYS Meshing. Do obliczeń modelu zastosowano solver ANSYS Fluent. Chemizm procesu spalania opisano za pomocą zredukowanych mechanizmów reakcji. Zaprezentowane wyniki dotyczące rozkładu temperatury, koncentracji substratów i produktów reakcji chemicznych oraz turbulentności ich strumieni w komorze wtórnej zostały omówione pod kątem kolejnych planowanych zmian, m.in. w zakresie sposobu doprowadzania powietrza.
\end{abstract}

Słowa kluczowe: spalanie, biomasa, kotły, modelowanie, CFD

${ }^{1}$ Autor do korespondencji / corresponding author: Mateusz Szubel, AGH w Krakowie, Wydział Energetyki i Paliw, al. Mickiewicza 30, 30-059 Kraków; tel. 126173428; mszubel@agh.edu.pl

2 Magdalena Papka, AGH w Krakowie, Wydział Energetyki i Paliw, al. Mickiewicza 30, 30-059 Kraków; papkamagda@gmail.com

3 Mariusz Filipowicz, AGH w Krakowie, Wydział Energetyki i Paliw, al. Mickiewicza 30, 30-059 Kraków; tel.126175192; filipow@agh.edu.pl 


\section{Wprowadzenie}

Zjawiska charakterystyczne dla pracy kotłów na biomasę opisane pokrótce w niniejszym artykule dowodzą faktu, iż mino relatywnie prostej konstrukcji, spalanie $\mathrm{w}$ tego typu jednostkach jest niezwykle skomplikowanym procesem $[1,2]$. W porównaniu do kotłów na paliwa konwencjonalne (w tym węgiel kawałkowy i „ekogroszek”, olej opałowy czy gaz ziemny), procesy zachodzące w komorach spalania urządzeń zasilanych biomasą są zdecydowanie mniej przewidywalne, a samo spalanie przebiega w sposób bardziej gwałtowny i zmienny (zarówno w zakresie czasowych i przestrzennych rozkładów temperatury jak i emisji zanieczyszczeń) [3, 4]. Determinuje to konieczność prowadzenia zaawansowanych, czasochłonnych i kosztownych prac w celu optymalizacji spalania $\mathrm{w} w / \mathrm{w}$ jednostkach grzewczych.

Naprzeciw wymaganiom związanym z takimi badaniami wychodzą metody komputerowe, wśród których na szczególną uwagę zasługuje obliczeniowa mechanika płynów CFD (ang. Computational Fluid Dynamics). CFD bazując przede wszystkim na tzw. metodzie objętości skończonych umożliwia prześledzenie procesów zachodzących w komorze spalania danego kotła, bez konieczności budowy wielu prototypów, skracając tym samym czas i koszt badań $[5,6]$.

Zespół Katedry Zrównoważonego Rozwoju Energetycznego Wydziału Energetyki i Paliw AGH w Krakowie wykorzystuje CFD do analiz procesów spalania w komercyjnych kotłach zasilanych biomasą. Wsparcie testów prowadzonych na stanowiskach doświadczalnych symulacjami CFD umożliwiło m.in. opracowanie nowej jednostki grzewczej. Obecnie, na etapie budowy instalacji w/w kotła prowadzone są analizy CFD, umożliwiające wstępne określenie rekomendowanych warunków jego pracy, jeszcze przed rozruchem.

\section{Proces spalania a piroliza i zgazowanie biomasy}

Spalanie biomasy obejmuje liczne procesy fizykochemiczne o wysokim stopniu złożoności [7, 8]. Rozpatrując w/w grupę paliw, Należy zwrócić szczególną uwagę na dużą zawartość wilgoci i części lotnych, co determinuje cztery ogólne fazy spalania: nagrzewanie i suszenie, termiczna dekompozycja komponentów paliwa, spalanie produktów rozkładu termicznego, spalenie pozostałości koksowej.

Piroliza biomasy to niekompletny rozkład termiczny, którego produktami są: karbonizat, kondensaty, smoła oraz gaz. Wśród produktów ciekłych należy wymienić wodę, kwas octowy i mrówkowy, aceton, formaldehyd, acetaldehyd, fenol, toluen i wiele innych. Natomiast najważniejsze składniki gazu pirolitycznego to wodór, para wodna, tlenek węgla, dwutlenek węgla, metan oraz wysokouwęglone węglowodory. Smoła stanowi mieszaninę związków aromatycznych [9]. Konwencjonalna piroliza prowadzi do wspomnianego wyżej formowania karbonizatu. W pirolizie szybkiej natomiast należy się spodziewać powstawania większej ilości ciekłych węglowodorów [7, 8]. 
Zgazowanie biomasy zachodzi przy udziale czynnika zgazowującego i niedoborze tlenu, przy czym proces może być alotermiczny i autotermiczny. Prekursorem procesu zgazowania jest piroliza lignino-celulozy z wydzielaniem części lotnych $[8,9]$. Czynnik zgazowujący reaguje ze stałym węglem oraz złożonymi węglowodorami wchodzącymi w skład lotnych produktów pirolizy, czego wynikiem jest ich przekształcenie w gazy o niewielkiej masie cząsteczkowej, jak tlenek węgla $(\mathrm{CO})$ i wodór $\left(\mathrm{H}_{2}\right)$.

\section{Obliczeniowa mechanika płynów w badaniach kotlów na biomasę}

Xue, Heindel i Fox w swojej pracy [10] zaproponowali model CFD do opisu procesu ciągłej szybkiej pirolizy biomasy w reaktorze ze złożem fluidalnym. Autorzy artykułu definiując kinetykę reakcji uwzględnili fakt wielostopniowości rozpatrywanego procesu, jak i występowanie w paliwie różnych składników, charakteryzujących się specyficznymi właściwościami: celulozy, hemicelulozy i ligniny. Analiza uwzględniała dynamikę ogrzewania cząstek paliwa, reakcje w fazie stałej, w tym proces formowania karbonizatu, a także przestrzenny rozkład smoły i gazów w reaktorze. Podobne zagadnienia są podejmowane w pracy Blondeau i Jeanmart [11], gdzie zaproponowano rozbudowany model opisujący pirolizę cząstek paliwa w kotle pyłowym.

Wyniki modelowania podstawowych zjawisk towarzyszących pirolizie drobin paliwa, jak również dane uzyskane w wyniku prac eksperymentalnych często są wykorzystywane do prowadzenia symulacji bardziej złożonych układów, w tym palenisk ze stałym złożem paliwa $[12,13]$. Budowa modelu numerycznego opisującego heterogeniczne spalanie biomasy, przy uwzględnieniu danych doświadczalnych i walidacji wyników obliczeń, pozwala na prowadzenie analiz wariantowych, skoncentrowanych m.in. na parametrach takich jak wpływ na proces i bilans cieplny jednostki współczynnika nadmiaru powietrza, zastosowania stopniowania powietrza, czy choćby ustawienia i kierunku wlotów powietrza pierwotnego i wtórnego $[14,15,16]$.

$\mathrm{W}$ oparciu o dane literaturowe możliwe jest przygotowanie symulacji numerycznych kotłów wsadowych niewielkiej mocy zasilanych słomą. Obecnie takie zastosowanie CFD dopiero zyskuje popularność, przy czym istnieją już opracowania opisujące modele pracy urządzeń spalających słomę [17]. W dalszej części niniejszej pracy opisano budowę modelu kotła typu EKOPAL RM-30, przystosowanego konstrukcyjnie do zaawansowanych testów eksperymentalnych (dodatkowe dysze powietrza wtórnego, liczne króćce montażowe czujników itp.). 


\section{Model CFD procesu spalania w komorze wtórnej kotła wsadowego zasilanego słomą}

W ramach opisywanych analiz opracowano model CFD oparty na uśrednianiu Reynoldsa w stanie pseudoustalonym (ang. Reynolds Averaged Navier Stokes - RANS) procesu homogenicznego spalania, obejmujący komorę wtórną wraz z sekcją odstojnika pyłów kotła zasilanego słomą. W badanym typie jednostek w komorze wtórnej następuje dopalenie produktów zgazowania słomy (zachodzącego w komorze pierwotnej), przy udziale powietrza wtórnego dostarczanego przez dysze umieszczone na bocznych ścianach komory. Motywacją do budowy modelu był fakt, iż stopień dopalenia w/w związków, a przez to także strata niezupełnego spalania oraz strata kominowa są ściśle związane z liczbą punktów podawania powietrza wtórnego oraz ich rozlokowaniem. Wynika to z konieczności zapewnienia odpowiedniej turbulentności przepływu gazów oraz dostępności utleniacza w obszarze reakcji chemicznych.

Rysunek 1 przedstawia geometrię modelowanej komory wtórnej po procesie dyskretyzacji (generacji siatki), w wyniku której uzyskano $1,7435 \cdot 10^{6}$ objętości skończonych. Siatka została poddana walidacji. Współczynnik jakości obliczany na podstawie stosunku objętości elementu siatki do sumy jego krawędzi osiągnął średnią wartość 0,9 , przy czym $1,31 \cdot 10^{6}$ elementów cechowało się wartością wskaźnika równą 0,95 (im wynik bliższy jest liczbie 1 , tym wyższa jakość elementu siatki, im bliższy 0 tym gorsza jakość).

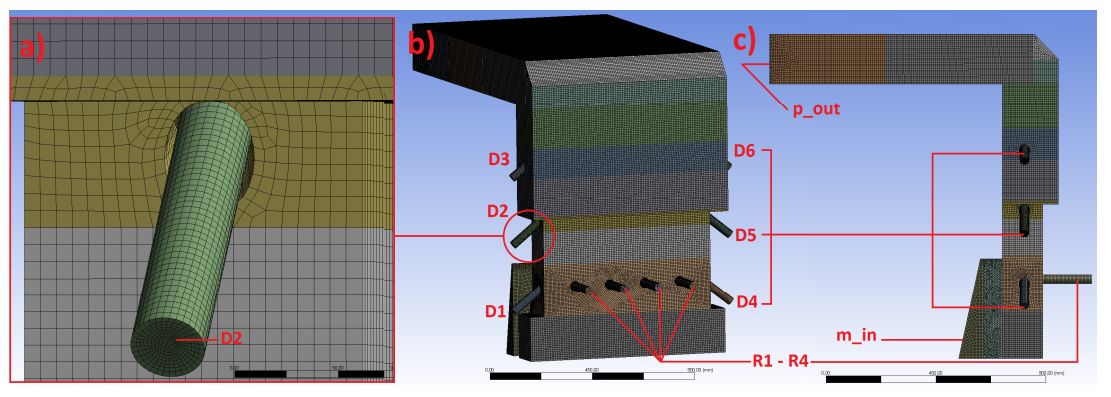

Rys. 1. Geometria przestrzenna komory wtórnej (część pionowa) i odstojnika pyłów (górna część pozioma) po przeprowadzeniu dyskretyzacji domeny ciągłej - zbliżenie prezentujące siatkę obliczeniową (a), widok 3D (b): R1 - R4-dysze powietrza pierwotnego, D1-D6-dysze powietrza wtórnego, oraz wi-

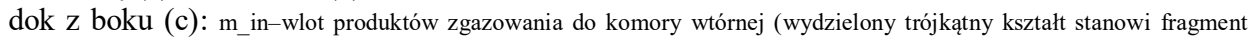
komory pierwotnej wypełnionej słomą), p_out-wylot spalin z obszaru domeny obliczeniowej

Fig. 1. Spatial geometry of the secondary chamber (vertical part) and the ash separator (top horizontal part) after the process of discretization of the computational domain - zoom presenting computational grid (a), 3D view (b): R1 - R4-primary air nozzles, D1 - D2-secondary air nozzles, and side view (c): $m$ in-inlet of products of the gasification to the chamber (separated triangle element is part of the primary chamber filled by straw), p_out-outlet of exhaust from the computational domain 
Tabela 1. Warunki brzegowe wlotowe w analizowanych wariantach doprowadzania powietrza

Table 1. Inlet boundary conditions in analyzed variants of air feeding

\begin{tabular}{|c|c|c|c|c|c|c|c|c|c|c|}
\hline \multirow{2}{*}{ Wariant } & $\mathrm{R} 1$ & R2 & R3 & $\mathrm{R} 4$ & D1 & D2 & D3 & D4 & D5 & D6 \\
\hline & \multicolumn{10}{|c|}{$[\mathrm{g} / \mathrm{s}]$} \\
\hline 1 & \multirow{7}{*}{15,5} & \multirow{7}{*}{18,5} & \multirow{7}{*}{18,5} & \multirow{7}{*}{15,5} & 16,6 & $x$ & $\mathrm{X}$ & 16,6 & $\mathrm{x}$ & $x$ \\
\hline 2 & & & & & $\mathrm{x}$ & 16,6 & $\mathrm{X}$ & $\mathrm{x}$ & 16,6 & $\mathrm{x}$ \\
\hline 3 & & & & & $x$ & $\mathrm{x}$ & 16,6 & $x$ & $\mathrm{x}$ & 16,6 \\
\hline 4 & & & & & 8,4 & 8,4 & $\mathrm{x}$ & 8,4 & 8,4 & $\mathrm{x}$ \\
\hline 5 & & & & & 5,53 & 5,53 & 5,53 & 5,53 & 5,53 & 5,53 \\
\hline 6 & & & & & 16,6 & 16,6 & $\mathrm{X}$ & 16,6 & 16,6 & $\mathrm{X}$ \\
\hline 7 & & & & & 16,6 & 16,6 & 16,6 & 16,6 & 16,6 & 16,6 \\
\hline
\end{tabular}

Warunki brzegowe wejściowe obejmowały wlot produktów zgazowania biomasy $(m$ in $=0,015 \mathrm{~kg} / \mathrm{s}, T=573,15 \mathrm{~K})$ przez obszar ciała porowatego oraz wloty powietrza pierwotnego i wtórnego. Przeprowadzono symulacje dla kilku wariantów pracy układu doprowadzania powietrza. Tabela 1 zawiera informacje na temat dysz pracujących w poszczególnych badanych wariantach. Na wylocie $\mathrm{z}$ komory spalania założono podciśnienie wynikające $\mathrm{z}$ rekomendowanego przez producenta ciągu kominowego ( $p \_o u t=-20 \mathrm{~Pa}$ ).

Równania transportu oparto na modelu turbulencji k- $\varepsilon$ realizable, którego cechą charakterystyczną jest zmodyfikowanie członu dyssypacji turbulencji, a także zastąpienie stałej $\mathrm{w}$ innych modelach lepkości turbulentnej zależnością funkcyjną [17]. W modelu promieniowania uwzględniono wpływ jego absorpcji przez cząsteczki trójatomowe (model typu „Weighted sum of gray gases model” - WSGGM).

Aby dobrze odzwierciedlić kinetykę reakcji syntezy i rozpadu o różnym stopniu wpływu turbulencji, konieczne było zastosowanie kombinacji modelu opartego na równaniu Arrheniusa (ang. Finite Rate), odpowiedniego w przypadku wartości parametru Damköhlera w układzie $\mathrm{Da}>1$ oraz modelu bazującego na stałej mieszania substratów i produktów (ang. Eddy Dissipation), gdzie $\mathrm{Da}<1$. $\mathrm{W}$ modelu uwzględniono 8 reakcji chemicznych, przy czym w zbiorze substratów wchodzących w skład produktów zgazowania znalazły się: $\mathrm{H}_{2}, \mathrm{O}_{2}, \mathrm{CO}$, $\mathrm{CH}_{4}, \mathrm{NH}_{3}, \mathrm{NO}, \mathrm{HCN}$, natomiast wśród produktów ich spalania należy wymienić: $\mathrm{H}_{2} \mathrm{O}, \mathrm{CO}_{2}, \mathrm{CO}, \mathrm{H}_{2}, \mathrm{NO}, \mathrm{N}_{2}$. Pełny opis chemizmu procesu można znaleźć $\mathrm{w}[16]$.

$\mathrm{Na}$ podstawie modelu określono wartości istotnych elementów bilansu cieplnego kotła. Rysunek 2a przedstawia wartości straty kominowej (metoda Siegerta) oraz straty niezupełnego spalania uzyskane w poszczególnych badanych wariantach. Niniejsze straty wraz z metodologią obliczeń zostały opisane w [9]. Ponieważ rozpatrywane składniki bilansu są ściśle związane z temperaturą spalin i emisją $\mathrm{CO}$, wartości tych parametrów w poszczególnych wariantach zestawiono na Rysunku $2 b$. 


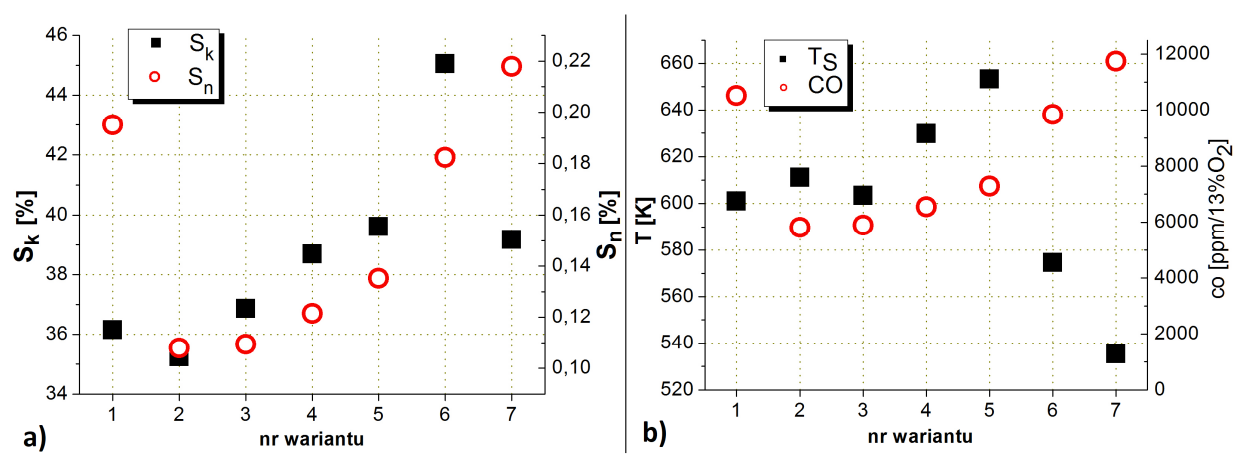

Rys. 2. Wartość straty kominowej $S_{k}$ i straty niezupełnego spalania $S_{n}(a)$, a także temperatura spalin i stężenie $\mathrm{CO}$ w spalinach (b) w zależności od rozpatrywanego wariantu doprowadzania powietrza

Fig. 2. Flue gas loss $S_{k}$ and incomplete combustion loss $S_{n}$ (a), as well as exhaust temperature and concentration of $\mathrm{CO}$ in exhaust (b) depending on the variant of air feeding

Mimo, iż temperatura spalin jak i koncentracja $\mathrm{CO}$ w przypadku wariantu drugiego nie są najniższe z pośród analizowanych wariantów, osiągnięto największą redukcję rozpatrywanych strat. Jest to wynik wpływu ulokowania wlotów powietrza wtórnego oraz jego strumienia na efektywność procesu spalania. Rysunek 3a prezentuje charakterystykę przepływu powietrza pierwotnego i wtórnego w komorze spalania w najkorzystniejszym wariancie.

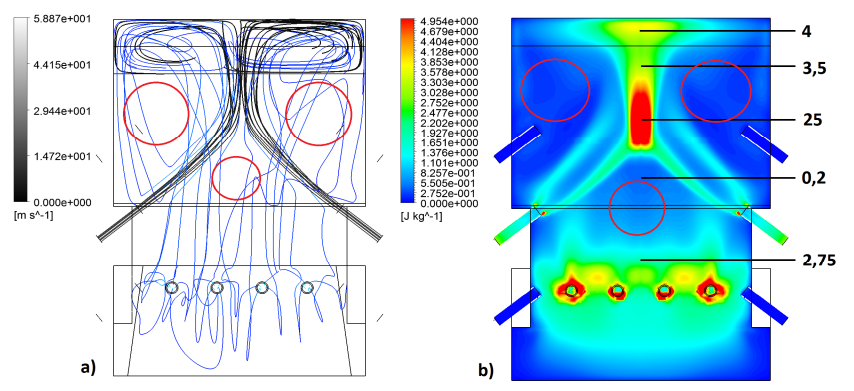

Rys. 3. Rozkład strumieni powietrza (a) oraz energii kinetycznej turbulencji w komorze wtórnej kotła - przekrój poprzeczy w płaszczyźnie symetrii dysz powietrza wtórnego (b) (widok z tyłu)

Fig. 3. Stream lines of air (a) and the turbulence kinetic energy in the secondary chamber of the boiler - cross sectional plane on the symmetry plane of the secondary air nozzles (b) (rear view)

Obszary o niewielkim stopniu mieszania reagentów zaznaczono okręgami. Są to rejony, gdzie decydującą role w spalaniu odgrywa temperatura (z uwagi na wpływ energii aktywacji na zachodzące reakcje). Poza tymi obszarami turbulentny przepływ gazów gwarantuje efektywne spalanie produktów zgazowania. Wartość energii kinetycznej turbulencji w komorze wtórnej przedstawia rysunek 3b. Wykorzystanie dysz powietrza wtórnego D2, D5 skutkuje powstaniem obszaru turbulentnego w odpowiedniej sekcji komory (centrum górnej części). 


\section{Podsumowanie}

Podejście do modelowania reakcji utleniacza i produktów zgazowania biomasy zaprezentowane w niniejszym artykule pozwala na efektywną analizę zjawisk towarzyszących homogenicznemu spalaniu w fazie gazowej, zachodzących w komorze wtórnej rozpatrywanego kotła. Wyniki modelowania numerycznego umożliwiły określenie udziału straty kominowej i straty niezupełnego spalania w bilansie jednostki grzewczej. Analiza wariantowa przeprowadzona z uwzględnieniem cech konstrukcyjnych instalowanego obecnie na stanowisku doświadczalnym kotła, już na etapie przygotowania urządzenia do rozruchu dostarczyła informacji w zakresie wpływu charakterystyki stopniowania powietrza na sprawność urządzenia i poziom emisji tlenku węgla. W celu rozszerzenia modelu należy w pierwszej kolejności rozważyć transport i spalanie w komorze wtórnej cząstek stałych, co zostanie zrealizowane poprzez wykorzystanie modelu DPM (ang. Discrete Phase Model).

Badania wykonane $w$ ramach prac statutowych, AGH w Krakowie, Wydziat Energetyki i Paliw, zadanie nr 11.11.210.217 p.t. "Badanie uwarunkowań zrównoważonego rozwoju energetycznego"

\section{Literatura}

[1] B. Sørensen: Renewable Energy Its physics, engineering, use, environmental impacts, economy and planning aspects, Academic Press, San Diego 2000.

[2] Rosendahl, Biomass combustion science, technology and engineering, Woodhead Publishing, Cambridge 2013.

[3] S. van Loo, J. Coppejan, The handbook of biomass combustion and co-firing, EARTHSCAN, London 2008.

[4] G.M. Joselin Herbert, A. Unni Krishnan, Quantifying environmental performance of biomass energy, Renewable and Sustainable Energy Reviews, vol. 59, 2016, pp. 292-308.

[5] L. Chaoqun, T. Jiyuan, Y. Guan-Heng, Computational Fluid Dynamics. A practical Approach, Butterworth-Heinemann, Oxford 2013.

[6] Z. Jaworski, Numeryczna Mechanika Płynów w Inżynierii Chemicznej i Procesowej, Akademicka Oficyna Wydawnicza EXIT, Warszawa 2005.

[7] P. Basu, Biomass gasification and pyrolysis practical design, Academic Press, Boston 2013.

[8] T.B. Johansson, H. Kelly, A.K.N. Reddy, R.H. Williams, Renewable Energy Sources for Fuels and Electricity, Island Press, Waszyngton 1993.

[9] S. Kruczek, Kotły: Konstrukcje i obliczenia, Oficyna Wydawnicza Politechniki Wrocławskiej, Wrocław 2001.

[10] Q. Xue, T. J. Heindel, R. O. Fox, A CFD model for biomass fast pyrolysisin in fluidized-bed reactors, Chemical Engineering Science, vo.66, 2011, pp. 2440-2452.

[11] J. Blondeau, H. Jeanmart, Biomass pyrolysis in pulverized-fuel boilers: Derivation of apparent kinetic parameters for inclusion in CFD codes, Proceedings of the Combustion Institute, vol.33, 2011, pp. 1787-1794. 
[12] M.A. Gómez, J. Porteiro, D. Patiňo, J.L. Miguez, Fast-solving thermally thick model of biomass particles embedded in a CFD code for the simulation of fixed bed burners, Energy Conversion and Management, vol. 105, 2015, pp. 30-44.

[13] R. Baczyński, R. Weber, A. Szlęk, Innovative design solution for small-scale domestic boilers: Combustion improvements using a CFD-based mathematical model, Journal of the Energy Institute, vol.88, 2015, pp. 53-63.

[14] J. Chaney, H. Liu, L. Li, An overview of CFD modelling of small-scale fixed-bed biomass pellet boilers with preliminary results from simplified approach.

[15] J. Collazo, J. Porteiro, J.L. Miguez, E. Granada, M.A. Gómez, Numerical Simulation of a small-scale biomass boiler, Energy Conversion and Management, vol. 64, 2012, pp. 87-96.

[16] M. Miltner, A. Makaruk, M. Harasek, A. Friedl, Computational fluid dynamic simulation of a solid biomass combustor: modelling approaches, Clean Technologies in Environmental Policy, vol. 10, 2008, pp. 165-174.

[17] Pliki pomocy ANSYS Workbench 15.

\title{
APPLICATION OF THE COMPUTATIONAL FLUID DYNAMICS IN VARIANT ANALYSIS OF HOMOGENEOUS COMBUSTION OF PRODUCTS OF BIOMASS GASIFICATION
}

\begin{abstract}
S u m m a r y
Due to necessity of diversification of energy sources, at the end of the last century manufacturers paid attention to technologies based on renewable energy sources, which have not been fully developed. Significant popularity has been gained by plant-based biomass, including wastes from agricultural production as well as energy crops. Modern approach assumes intensification biomass usage in distributed heat production. In rural areas, which are characterized by high availability of solid biofuels, application of batch biomass - fired boilers gives significant economical profits. Moreover, such units are environmental friendly, although combustion has to be carried out using appropriate air feeding system as well as according to dedicated control algorithm. Studies in range of optimization of operation of small scale biomass - fired heating units are conducted on Faculty of Energy and Fuels in AGH University of Science and Technology in Krakow. The paper presents the CFD numerical analysis of the $100 \mathrm{~kW}$ straw - fired batch boiler. Construction of the heating unit has been designed based on results of the studies carried out using standard design of the batch boiler. Numerical model has been developed based on the ANSYS Workbench 15 software.. Computations have been performed by ANSYS Fluent solver.
\end{abstract}

Keywords: combustion, biomass, boilers, modeling, CFD

Przestano do redakcji: 18.07.2017 r.

Przyjęto do druku: 15.12.2017 r. 